\title{
Integrating Diffusion of Innovation to Technology Acceptance Model: A Survey of Millennials' Intention to Use E-Money Card
}

\author{
Suresh Kumar ${ }^{1, *}$ Merlinda Dami ${ }^{2}$ \\ ${ }^{1}$ Faculty of Business - President University, Indonesia \\ ${ }^{2}$ PT Dok Widjaja Mandiri, Indonesia \\ *Corresponding Author. Email: sureshkumar@president.ac.id
}

\begin{abstract}
This study aims to investigate millennials' intentions to use the E-Money card. The variables examined in this study include perceived compatibility, trialability, complexity, perceived enjoyment, observability, perceived usefulness, innovativeness, perceived ease of use, relative advantage and usage intention. This study applied a quantitative research method with an online survey platform and distributed via media such as WhatsApp, Instagram, and Line. The questionnaire contained 34 questions. The sampling technique used was purposive sampling and obtained 435 respondents with 390 valid responses. All variables passed the validity and reliability test and no discriminant problems were found. For hypothesis analysis, this study applied. Results show that perceived ease of use and usefulness are influenced by relative advantage. Then, perceived ease of use is influenced by perceived compatibility, complexity, observability, and trialability. Further, innovativeness influences usage intention, perceived usefulness, and perceived ease of use influence usage intention. It is also found that there are no influences between perceived compatibility and usefulness. Moreover, complexity, observability, and trialability do not influence perceived usefulness and enjoyment, innovativeness does not influence perceived usefulness and ease of use, and lastly ease of use does not influence usefulness. This study contributes to the body of knowledge in regards to millennial usage of the E-Money card by integrating the Diffusion of Innovation theory with innovativeness to TAM.
\end{abstract}

Keywords: e-money card, DOI, TAM, innovativeness, perceived usefulness, perceived ease of use, behavior intention to use.

\section{INTRODUCTION}

Nowadays, along with the advancement of digital technologies, the need for electronic money cards has increased rapidly and financial transactions have become easier. E-money is used as a payment instrument in replace to cash money which is stored electronically on a server or chip and can also be refilled and used for various types of payments such as public transportation, toll roads, and shops that work with publishers, namely banks and institutions other than a bank under license from Bank Indonesia. Generation Z or commonly known as millennials are the generation with the highest percentage of non-cash transaction usage. The use of E-Money is a form of the National Non-Cash Movement (GNNT). This movement is formed to extend users mindfulness to utilize non-cash instruments to form a new community called the Less Cash Society (LCS), particularly in conducting exchanges for financial activities [1]. Flazz BCA, Mandiri E-money, BRI Brizzi, and BNI Tapcash are the best and most popular e-money products in Indonesia [2].

Bank Indonesia noted that by August 2018 E-Money transactions had increased by more than $300 \%$. The volume of electronic money transactions until August 2018 was 297.4 million transactions, up 375\% year on year and the same period last year which was only 62 million transactions. The nominal value of E-Money transactions reached IDR 3.8 trillion, up 393\% year on year from the same period last year of IDR 790 billion. This increase was partly due to the use of electronic money on toll roads that began on October 30, 2017. The volume and value of electronic money transactions indicate that the growth is significant comparing November 2017 against November 2018. The total transactions reached IDR 5.19 trillion or an increase of $216.46 \%$ [3]. This increment happens with the aid of transportation purposes Trans Jakarta, KRL, MRT, toll, parking, etc. Thus, banks are issuing more and more card-based E-Money with a variety of functions and uses, so consumers could benefit by using e-money cards. As a result, there is an intense competition 
between banks to issue E-Money cards [4] to grab especially the millennials.

This study aims to investigate millennials' intentions to E-Money cards in Indonesia especially the Greater Jakarta area by examining the integration of Diffusion of innovation theory (DOI) and Technology acceptance model (TAM). Research questions to be addressed in this study are do relative advantage, perceived compatibility, complexity, observability, trialability, perceived enjoyment, and innovativeness significantly influence perceived usefulness and ease of use? To what extent does innovativeness influence usage intention? Do perceived usefulness and perceived ease of use significantly influence behavior intention to use? Does perceived ease of use significantly influence usage intention? This study is organized as follows: the next section is elaborating the hypothesis development and research gap, with the method in the third chapter. The fourth chapter is analyzing the collected data and the conclusion, managerial implications, and future recommendations are given in the fifth chapter.

\section{HYPOTHESIS DEVELOPMENT}

\subsection{Relationship among variables}

The perceived relative advantages are the drivers of consumers' intention to utilize the program through various participants. Nevertheless, exploring studies regarding IDT and TAM, the relationships among the variables were rarely studied. However, it is believed that a higher level of technological usefulness is perceived when higher relative advantages are perceived by users [13].

H1: Relative Advantage significantly influences PU

$\mathrm{H} 2$ : Relative Advantage significantly influences PEU

The degree of encounter with comparative technologies was significantly related with confidence in the ease of use about the headway of the latest technology. Past studies confirm the influence of compatibility towards PU, PEOU, and the usage intention [13]. However, potential customers would not have adopted a new service just because of its compatibility [14].

H3: Perceived Compatibility significantly influences PU

H4: Perceived Compatibility significantly influences PEU

Complexity has a negative effect on PEU, indicating that complexity and PEOU are two different conceptions. It is also has a negative direct effect on PU [15]. Based on the results from [16], found that complexity has a negative effect towards PU [17]

H5: Complexity significantly influences PU

H6: Complexity significantly influences PEU
When integrating DOI variables with TAM, observability has a direct impact on PU and PEU. Hence, users tend to employ innovations if people observe that the results have benefits. Such measurable characteristics are having a direct impact on PU and PEU based on the discussion presented in the following literature [15]. Based on the result from [16] also found out that there is a positive impact between observability towards PU and PEU [17].

H7: Observability significantly influences PU

H8: Observability significantly influences PEU

Trialability is the level at which people believe in the possibility of experiencing innovation before accepting or rejecting the innovation. The ability of trials (trialability) has a relationship to PU and PEU [16]. The technology is considered to be beneficial and user friendly once when it has a higher level of trialability [18].

H9: Trialability significantly influences PU

H10: Trialability significantly influences PU

Perceived enjoyment of technology can evaluate its perceived usefulness. Although some apps are designed solely for fun and enjoyment, others have a utilitarian aspect such as an educational purpose. Enjoyable technologies would be perceived as more beneficial because while people enjoy communicating with technology, they are not aware that they are also more efficient and productive [19].

H11: Perceived Enjoyment significantly influences PU H12: Perceived Enjoyment significantly influences PEU

According to [20], past studies have explored the driver factors of the acceptance of the technology and conclude that innovativeness is the prime driver for PU, PEU, and ultimately BIU. People with higher personal innovativeness create more strong beliefs about the target technology, so innovativeness significantly affects PEU and PU [20]. The adoption of technology is likely to happen when users have the higher level of innovativeness, hence innovativeness has a major effect on the usage intention to adopt the latest technology [21].

H13: Innovativeness significantly influences PU

H14: Innovativeness significantly influences PEU

H15: Innovativeness significantly influences BIU

PEU is the level of user confidence that the use of a particular system does not need to do much effort. Over the last few years, large studies have been carried out and provide empirical evidence that directly and indirectly the important effects of PEU on behavioral intentions affect perceived benefits and PEU positively affects PU. When certain systems are easy to use this has a positive impact on perceived usefulness [22]. Based on the study from [21] found that PU is influenced by how high PEU the user has [21]. 


\section{H16: PEU significantly influences PU}

Perceived Ease of Use is related to the individual understanding of how simple the new technology is to use. It is also seen as a trigger for the adoption of new technical advances. If the technological tool is perceived to be easy to use by students, it would be intended for students to use the new technology. It is also reasonable to conclude that PEU has a significant impact on the intention to use it. Perceived Usefulness is assumed to be the primary driver of user behavior. The effect of perceived Usefulness on Behavioral Intention is confirmed in more than 80 percent of TAM-based studies [23]. Based on the study from [21] found that perceived usefulness significantly influences behavior intention to use.

H17: PU significantly influences BIU

H18: PEU significantly influences BIU

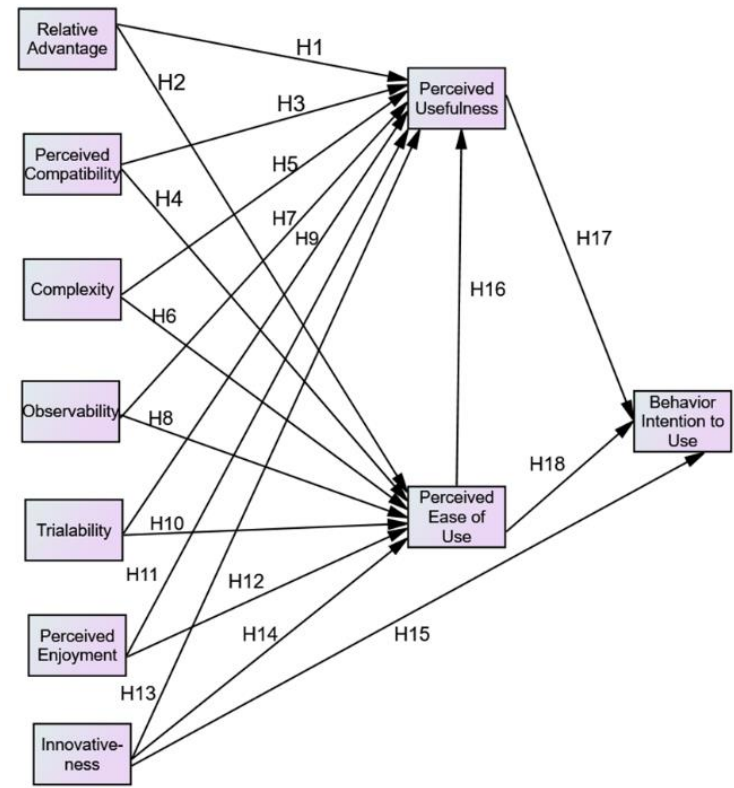

Figure 1. Theoretical Framework

\subsection{Research Gap}

There are few studies about the diffusion of innovation theory and technology acceptance model. A previous study by [13] only focused on compatibility, relative advantage, and complexity towards perceived usefulness, perceived ease of use, attitude, behavior intention of use, and actual use. According to [13], the topic of the study is financial technology (Fintech) and was conducted in Taiwan. A previous study by [15] only focused on relative advantage, compatibility, complexity, observability, and social influence towards PU, PEU, attitude, and future usage intention, also discuss insights from DOI and TAM and the topic is about Uber mobile application and conduct on the USA.

A previous study by [17], used the same variable in this study. This previous study aims to explore and investigate the potential factors influencing students' behavior to use the e-learning system. Whereas in this study, the researcher wants to investigate the influence of DOI and innovativeness to TAM of using an e-money card. The previous study was conducted in Malaysia whereas this study is conducted in Indonesia especially in the Greater Jakarta and also the topic between the previous study [17], and this study is different in the industry context.

\section{METHODS}

This research was conducted in Greater Jakarta, with a total respondent of 390 of age starting from 19 to 38 years old as millennial generations and using an EMoney card. The study applied a quantitative approach with a survey method as the instrument to collect respondents' responses and purposive sampling as the technique to choose the respondents with the criteria those who use e-money (ex. E-Money Mandiri, Flazz BCA, Tap Cash BNI, Brizzi BRI, etc.) for daily expenditure and millennia. The instrument consists of 34 item statements which were taken from past studies, such as behavior intention to use (BIU) is measured by 3 items from [24]; perceived ease of use (PEU) is measured by 4 items from [25]; perceived usefulness (PU) is measured by 5 items from [26]; perceived enjoyment is measured by 3 items from [27] innovativeness is measured by 6 items from [28]; Trialability is measured by 2 items from [10]; observability is measured by 2 items from [12]; complexity is measured by 3 items from [29]; perceived compatibility is measured by 3 items from [30], and the relative advantage is measured by 3 items from [12]. The responses were measured using Likert-type scales range 7 degrees. Likert-type scales are developed whereby a specific item is assessed based on how well it discriminates between individuals whose total score is high and those with a low score [31].

Collected data were checked for construct validity (convergent and discriminant validity) and reliability. Convergent validity is evaluated by Average Variance Extracted (AVE) in all items relevant to the organization with the criteria greater than 0.5 [32]. According to [33] discriminant validity is defined as the extent to which constructs differ empirically with each other and suggested the use of Fornell-Larker by comparing the square root of Average Variance Extracted (AVE) with latent correlation. According to [34] reliability involves stability and is consistent with a measurement of the results of phenomena and repetition and the most common method used is Composite Reliability coefficient value is greater than 0.7 .

The valid and reliable data then were tested for their model fit as the requirement to use the Structural Equation Model. To confirm the compatibility of the model with the data, the Goodness of Fit (GoF) 
measures are used including the Comparative Fit Index (CFI>0.9), Root Approved Error Error Approximation (RMSEA<0.08), Chi-Square ( $>5$ ), Adjusted Goodness of Fit (AGFI>0.9) Index, Goodness-of-Fit Index (GFI>0.9), and Tucker-Lewis Index (TLI>0.9) [35]. [33] also suggest having at least 5 criteria are fit-out of seven since it is sometimes difficult to achieve all fit for the model, specially AGFI and GFI.

Once the model is fit, then the hypothesis testing can be applied with the criteria p-value < 0.05 [36] and the strength of the structural model with R-square ranging from 0 to 1 , with a greater rate of predictive accuracy. There are 3 types of $\mathrm{R}^{2}$ values of 0.75 (substantial), 0.50 (moderate), and 0.25 (weak) [37].

\section{RESULT AND DISCUSSION}

The result (Table 1) shows that the majority of respondents are female with a total response of 297 (76.2\%) and aged around 19-25 years old. Most of them are from college $(90.5 \%)$ and mostly under degree (S1). Most of their occupation is as an employee (50.3\%) and also a student (46.2\%). Monthly spending to use EMoney mostly around IDR 100.000,00 -IDR $150.000,00$ (40.5\%) and IDR 200.000,00 - IDR $250.000,00(33.8 \%)$.

Table 1. Respondents' Profile

\begin{tabular}{|c|c|c|c|}
\hline Variables & Categories & Frequency & Percentage \\
\hline \multirow{2}{*}{ Gender } & Female & 297 & $76.20 \%$ \\
\hline & Male & 93 & $23.80 \%$ \\
\hline \multirow{2}{*}{ Age Group } & $19-25$ years old & 346 & $88.70 \%$ \\
\hline & 26-32 years old & 43 & $11 \%$ \\
\hline \multirow{5}{*}{$\begin{array}{l}\text { Education } \\
\text { Level }\end{array}$} & High School & 28 & $7.20 \%$ \\
\hline & Diploma & 8 & $2.10 \%$ \\
\hline & Under Degree (S1) & 353 & $90.50 \%$ \\
\hline & Post Degree (S2) & - & - \\
\hline & Professional & - & - \\
\hline \multirow{4}{*}{ Occupation } & Employee & 196 & $50.30 \%$ \\
\hline & Self-employed & 4 & $1.00 \%$ \\
\hline & Entrepreneur & 10 & $2.60 \%$ \\
\hline & Student & 180 & $46.20 \%$ \\
\hline \multirow{5}{*}{$\begin{array}{l}\text { Monthly } \\
\text { spending to } \\
\text { use E- } \\
\text { Money } \\
\text { Card }\end{array}$} & IDR $50.000,00$ & 60 & $15.40 \%$ \\
\hline & IDR100.000,00- IDR $150.000,00$ & 158 & $40.50 \%$ \\
\hline & IDR $200.000,00$ - IDR $250.000,00$ & 132 & $33.80 \%$ \\
\hline & IDR $300.000,00$ - IDR $350.000,00$ & 15 & $3.80 \%$ \\
\hline & $>$ IDR 400.000,00 & 17 & $4.40 \%$ \\
\hline
\end{tabular}

Checking on the construct validity (Table 2), it shows that all variables are valid based on AVE value which is greater than 0.5 (Relative advantage $=0.61$; perceived compatibility $=0.71$; complexity $=0.63$; observability $=0.78 ;$ trialability $=0.76 ;$ perceived enjoyment $=0.73$; innovativeness $=0.61 ; \mathrm{PU}=0.65$; PEU $=0.68$, behavior intention to use $=0.66$ ). There are also no discriminant problems found in the result since all correlations (0.31-0.82) among construct are lower than square root of AVE (0.89-0.92) of each construct.

Testing on the reliability (Table 2), it also shows that all constructs are reliable since the Composite
Reliability $(\mathrm{CR})$ results are greater than 0.70 (Relative advantage $=0.82 ;$ perceived compatibility $=0.88$; complexity $=0.84 ;$ observability $=0.87 ;$ trialability $=$ 0.87 ; perceived enjoyment $=0.89$; innovativeness $=$ $0.90 ; \mathrm{PU}=0.85$; PEU 0.89, and behavior intention to use $=0.85$ ).

Table 2. Validity and Reliability results

\begin{tabular}{|c|c|c|c|c|}
\hline Factor & Item & $\begin{array}{c}\text { Factor } \\
\text { Loading }\end{array}$ & $\mathrm{AVE}$ & $\mathrm{CR}$ \\
\hline \multirow{3}{*}{$\begin{array}{c}\text { Relative } \\
\text { Advantage }\end{array}$} & RA 1 & 0.773 & \multirow{3}{*}{0.61} & \multirow{3}{*}{0.82} \\
\hline & RA 2 & 0.774 & & \\
\hline & RA 3 & 0.796 & & \\
\hline \multirow{3}{*}{$\begin{array}{c}\text { Perceived } \\
\text { Compatibility }\end{array}$} & PCo 1 & 0.774 & \multirow{3}{*}{0.71} & \multirow{3}{*}{0.88} \\
\hline & $\mathrm{PCo} 2$ & 0.898 & & \\
\hline & PCo3 & 0.859 & & \\
\hline \multirow{3}{*}{ Complexity } & Cx1 & 0.631 & \multirow{3}{*}{0.63} & \multirow{3}{*}{0.84} \\
\hline & $\mathrm{Cx} 2$ & 0.884 & & \\
\hline & $\mathrm{Cx} 3$ & 0.85 & & \\
\hline \multirow{2}{*}{ Observability } & Obs1 & 0.835 & \multirow{2}{*}{0.78} & \multirow{2}{*}{0.87} \\
\hline & Obs 2 & 0.926 & & \\
\hline \multirow{2}{*}{ Trialability } & Tril & 0.876 & \multirow{2}{*}{0.76} & \multirow{2}{*}{0.87} \\
\hline & Tri2 & 0.871 & & \\
\hline \multirow{3}{*}{$\begin{array}{l}\text { Perceived } \\
\text { Enjoyment }\end{array}$} & PEj1 & 0.815 & \multirow{3}{*}{0.73} & \multirow{3}{*}{0.89} \\
\hline & PEj2 & 0.872 & & \\
\hline & PEj3 & 0.878 & & \\
\hline \multirow{6}{*}{$\begin{array}{c}\text { Innovativene } \\
\text { ss }\end{array}$} & Inn 1 & 0.654 & \multirow{6}{*}{0.61} & \multirow{6}{*}{0.9} \\
\hline & $\operatorname{Inn} 2$ & 0.798 & & \\
\hline & Inn3 & 0.899 & & \\
\hline & Inn 4 & 0.768 & & \\
\hline & Inn5 & 0.742 & & \\
\hline & Inn6 & 0.816 & & \\
\hline \multirow{3}{*}{$\begin{array}{l}\text { Perceived } \\
\text { Usefulness }\end{array}$} & PU3 & 0.733 & \multirow{3}{*}{0.65} & \multirow{3}{*}{0.85} \\
\hline & PU4 & 0.888 & & \\
\hline & PU5 & 0.789 & & \\
\hline \multirow{4}{*}{$\begin{array}{c}\text { Perceived } \\
\text { Ease of Use }\end{array}$} & PEU1 & 0.83 & \multirow{4}{*}{0.68} & \multirow{4}{*}{0.89} \\
\hline & PEU2 & 0.83 & & \\
\hline & PEU3 & 0.838 & & \\
\hline & PEU4 & 0.789 & & \\
\hline \multirow{3}{*}{$\begin{array}{c}\text { Behavior } \\
\text { Intention of } \\
\text { Use }\end{array}$} & BIU1 & 0.807 & \multirow{3}{*}{0.66} & \multirow{3}{*}{0.85} \\
\hline & BIU2 & 0.815 & & \\
\hline & BIU3 & 0.807 & & \\
\hline
\end{tabular}

As required, the model fit was testing and it shows that it is a good model $(\mathrm{CMIN} / \mathrm{DF}=3.467 \mathrm{GFI}=0.924$; $\mathrm{AGFI}=0.871 ; \mathrm{IFI}=0.937 ; \mathrm{TLI}=0.947 ; \mathrm{CFI}=0.938$; RMSEA $=0.068$ ). Having a fit model, the analysis was further conducted to check on the hypothesis testing (Table 3). the result shows Relative Advantage has a significant influence toward PU $(C R=4.393 ; \beta=0.457$; $\mathrm{p}=0.000)$, Relative Advantage has a significant influence toward PEU $(\mathrm{CR}=3.953 ; \beta=0.449 ; \mathrm{p}=$ 0.000), Perceived Compatibility has no significant influence toward PU $(\mathrm{CR}=0.101 ; \beta=0.009 ; \mathrm{p}=0.920)$, Perceived Compatibility has a significant influence 
toward PEU (CR $=-2.313 ; \beta=-0.258 ; \mathrm{p}=0.021)$, Complexity has no significant influence toward PU (CR $=1.272 ; \beta=0.118 ; \mathrm{p}=0.203)$, Complexity has a significant influence toward PEU $(\mathrm{CR}=5.866 ; \beta$ $=0.603 ; \mathrm{p}=0.000)$, Observability has no significant influence toward PU $(\mathrm{CR}=-0.006 ; \beta=0.000 ; \mathrm{p}$ $=0.995)$, Observability has a significant influence toward PEU $(\mathrm{CR}=-2.573 ; \beta=-0.125 ; \mathrm{p}=0.010)$, Trialability has a significant influence toward PU $(\mathrm{CR}=$ $-0.275 ; \beta=-0.011 ; p=0.783)$, Trialability has a significant influence toward PEU $(\mathrm{CR}=-2.153 ; \beta=$ $0.109 ; \mathrm{p}=0.031)$, Perceived Enjoyment has no significant influence toward PU $(\mathrm{CR}=1.608 ; \beta=0.153$; $\mathrm{p}=0.108)$, Perceived Enjoyment has no significant influence toward PEU $(\mathrm{CR}=1.960 ; \beta=0.235 ; \mathrm{p}=$ $0.050)$, Innovativeness has no significant influence toward PU $(\mathrm{CR}=1.200 ; \beta=0.038 ; \mathrm{p}=0.230)$, Innovativeness has no significant influence toward PEU $(\mathrm{CR}=0.644 ; \beta=0.038 ; \mathrm{p}=0.519)$, Innovativeness has a significant influence toward $\mathrm{BIU}(\mathrm{CR}=2.514 ; \beta=$ $0.157 ; \mathrm{p}=0.012)$, PEU has no significant influence toward PU $(\mathrm{CR}=1.598 ; \beta=0.121 ; \mathrm{p}=0.110)$, PU has a significant influence toward BIU $(\mathrm{CR}=7.548 ; \beta=$ 0.777; $\mathrm{p}=0.000)$, PEU has a significant influence toward $\mathrm{BIU}(\mathrm{CR}=3.009 ; \beta=0.242 ; \mathrm{p}=0.003)$. The strength of the model also shows great strength where behavioral intention to use showed $65.7 \%$.

Table 3. Hypothesis results

\begin{tabular}{|c|c|c|c|c|c|}
\hline Hypothesis & Statement & Estimate & C.R. & P & Conclusion \\
\hline H1 & RA $\rightarrow$ PU & $\mathbf{0 . 4 5 7}$ & $\mathbf{4 . 3 9 3}$ & $\mathbf{0 . 0 0 1}$ & Accepted \\
\hline H2 & RA $\rightarrow$ PEU & $\mathbf{0 . 4 4 9}$ & $\mathbf{3 . 9 5 3}$ & $\mathbf{0 . 0 0 1}$ & Accepted \\
\hline H3 & PCo $\rightarrow$ PU & 0.009 & 0.101 & 0.92 & Rejected \\
\hline H4 & PCo $\rightarrow$ PEU & $\mathbf{- 0 . 2 5 8}$ & $\mathbf{- 2 . 3 1 3}$ & $\mathbf{0 . 0 2 1}$ & Accepted \\
\hline H5 & Cx $\rightarrow$ PU & 0.118 & 1.272 & 0.203 & Rejected \\
\hline H6 & Cx $\rightarrow$ PEU & $\mathbf{0 . 6 0 3}$ & $\mathbf{5 . 8 6 6}$ & $\mathbf{0 . 0 0 1}$ & Accepted \\
\hline H7 & Obs $\rightarrow$ PU & 0 & -0.006 & 0.995 & Rejected \\
\hline H8 & Obs $\rightarrow$ PEU & $\mathbf{- 0 . 1 2 5}$ & $\mathbf{- 2 . 5 7 3}$ & $\mathbf{0 . 0 1}$ & Accepted \\
\hline H9 & Tri $\rightarrow$ PU & -0.011 & -0.275 & 0.783 & Rejected \\
\hline H10 & Tri $\rightarrow$ PEU & $\mathbf{- 0 . 1 0 9}$ & $\mathbf{- 2 . 1 5 3}$ & $\mathbf{0 . 0 3 1}$ & Accepted \\
\hline H11 & PEj $\rightarrow$ PU & 0.153 & 1.608 & 0.108 & Rejected \\
\hline H12 & PEj $\rightarrow$ PEU & 0.235 & 1.96 & 0.05 & Rejected \\
\hline H13 & INN $\rightarrow$ PU & 0.056 & 1.2 & 0.23 & Rejected \\
\hline H14 & INN $\rightarrow$ PEU & 0.038 & 0.644 & 0.519 & Rejected \\
\hline H15 & INN $\rightarrow$ BIU & 0.157 & 2.514 & 0.012 & Accepted \\
\hline H16 & PEU $\rightarrow$ PU & 0.121 & 1.598 & 0.11 & Rejected \\
\hline H17 & PU $\rightarrow$ BIU & $\mathbf{0 . 7 7 7}$ & $\mathbf{7 . 5 4 8}$ & $\mathbf{0 . 0 0 1}$ & Accepted \\
\hline H18 & PEU $\rightarrow$ BIU & $\mathbf{0 . 2 4 2}$ & $\mathbf{3 . 0 0 9}$ & $\mathbf{0 . 0 0 3}$ & Accepted \\
\hline & & & & & \\
\hline
\end{tabular}

This study found that relative advantage significantly influences the PU and PEU, which is supported by [13], [38]. Relative advantage is the same with PU which is the best indicator of acceptance of technology so if the relative advantage is higher than PU and PEU is higher too. This study also found that perceived compatibility did not influence perceived usefulness. In contrast to the previous study [13] which states that the compatibility effect was found to be significant only to PU. Furthermore, the relative advantage significantly influences PEU which is confirmed by [14].

The study found that complexity did not influence perceived usefulness which is supported by [15], [16]. Furthermore, complexity significantly influences the perceived ease of use which is in contrast to the study by [15], [16]. They stated that during the high complexity, the user will feel that the benefits of using an e-money card are reduced and affect the PEU.

In this study, observability did not influence PU. Perception of usefulness by others in the use of the emoney card certainly different from the other user too, depending on the needs. It is contrasted with the previous study by [15], [16] that found observability significantly influences perceived ease of use. Also, trialability did not influence perceived usefulness which is in contrast to the previous study by [16] where trialability significantly influences PEU.

Surprisingly, this study also found that perceived enjoyment did not influence PU and PEU, in contrast to the previous study by [19]. This research found that innovativeness did not influence perceived usefulness and ease of use. In contrast to the previous study by [39] that found innovativeness plays important role in PU and PEOU. However, this study found that innovativeness significantly influences behavior intention to use. It is supported by [40] which stated that the higher the level of innovativeness, the level of behavior intention to use e-money cards will be higher as well. Another surprising finding is that PEU did not influence PU which is in contrast to the findings of [22], [40], when technology is easy to use then it has a positive impact on PU.

Meanwhile, PU and PEU significantly influence BIU. It is supported by [23], [40]. PEU and PU of technology have a positive influence on BIU because the greater the degree of convenience and benefits, the greater the intention to use the technology.

\section{CONCLUSION}

Based on the result of the study, from 18 hypotheses, it can be concluded that there are 9 hypotheses are accepted (Relative advantage has a significant influence toward PU, Relative advantage has a significant influence toward PEU, perceived compatibility has a significant influence toward PEU, complexity has a significant influence toward PEU, observability has a significant influence toward PEU, Trialability has a significant influence toward PEU, Innovativeness has a significant influence toward BIU, PU has a significant influence toward BIU, PEU has a significant influence toward BIU. Integrating DOI and TAM is a good combination to see the acceptance of technology against innovation theory. From the results of the study, not all of the hypotheses are accepted, but this is sufficient to prove that these theories can influence millennial intention to use an e-money card. Thus this finding 
contributes to the body of knowledge regarding millennial intention to use e-money cards based on DOI and TAM

The bank issues e-money cards with a variety of advantages and disadvantages so that the bank provides facilities for consumers to be able to use e-money cards following the wishes and needs of the customer. This study focuses on behavior intention to use because it is important to determine individual behavior in the use of e-money cards. With innovation and e-money card technology, it makes it easy for customers to make transactions so that they can be more effective and save time. From the innovation, the customer will feel the benefits and feel the convenience because it is helped by technology such as e-money cards. In the field of transportation, such as transactions in Trans Jakarta, MRT, LRT, parking and even shopping in retail stores already adopt electronic money card technology.

In developing behavioral intention to use e-money cards, there are several implications. First, with the increasing number of electronic money card users in Indonesia, especially in the field of transportation, the benefits of using e-money cards such as to do transactions without having long queues and perform work activities more quickly and effectively. So from the bank can increase the efficiency and effectiveness of each e-money so that the public can feel more benefits considering the density of activities held when going to work or wherever using transportation, paying for parking, and paying toll road fees.

Second, the benefits of using e-money are very important for ease of use. banks can improve the emoney top-up system so that the obstacles when filling e-money card balances such as the system are often online or not available are reduced and prevent so that there are no obstacles such as already filling card balances but the balance in e-money cards does not increase. If things like this are considered, it will make e-money cards easier to use.

Third, perceived compatibility also influence to perceived ease of use. Banks must prioritize the convenience of e-money card users so they can feel comfortable and easy in using e-money. Then the bank can adjust the e-money system according to user needs and lifestyle. By providing attractive promotions for emoney card purchases and offering e-money cards that are practical, efficient, and do not require additional admin fees when filling e-money card balances.

Fourth, complexity also influences to perceived ease of use. E-money card usage does not need to require technical skills because the card is very easy to use and also practical. However, for some people who have never used an e-money card, it will be a little difficult to understand how to use it. So from that, banks can provide education to the public how the use of e-money cards and the benefits of e-money cards
Fifth, users will observe the use of e-money cards in advance by looking at how to use e-money cards from friends, family, or relatives, whether e-money cards are easy to use or not. Therefore, banks can increase user trust by providing the best service so that users can recommend brands from banks that provide the benefits of using their e-money cards.

Sixth, after observing, the public will try to use emoney cards recommended by friends, family, or relatives. Banks can see this opportunity by offering attractive offers and always making improvements if there are any complaints or suggestions from users, so users will be increasingly interested in using e-money cards from certain banks.

Seventh, innovation is very important so it certainly affects the perceived ease of use in using e-money cards. Therefore, banks can always provide interesting innovations in every e-money card offer by enforcing a practical top-up system, providing attractive discounts at the top-up system, increasing security in the top-up system and designing cards as funny and unique as possible, and collaboration with many universities so that card brands can be better known.

Eighth, many benefits of using e-money cards certainly have an impact on behavioral intention to use that e-money card. Therefore, as discussed, banks must provide benefits that are following the needs of users, provide creative innovation so that users can be interested in using the e-money card.

Ninth, to develop behavioral intention to use emoney cards, banks must make users feel the ease of using their e-money cards. The top-up system is often online, an error occurs at the top-up, the card cannot be scanned, must be considered by the bank because if the user has experienced this and has been disappointed with poor service, then the user will no longer trust and will switch to another bank instead of using e-money cards from previous banks.

This research helps banks to be able to improve innovation in making e-money cards, form innovations such as enforcing a practical top-up system, providing attractive discounts at the top-up system, increasing security in the top-up system, and designing cards as funny and unique as possible. The use of electronic money cards often used by millennials age who are happy with practical matters so that banks can add benefits by creating e-money card systems that are easily applied. Although in this study there are some insignificant variables, one of which is perceived enjoyment, which is insignificant towards PU and PEU, when customers already feel the benefits and ease of applying for e-money cards, then they will automatically enjoy the technology.

This research has some limitations and suggestions that could be useful for the next research. This study is only focusing on the users of e-money cards in the 
millennial age, so in the future research can target other e-money card users generally. Actually, in electronic money, there are various kinds both from banking and non-banking. This study only focuses on electronic money in the form of cards from banking such as Flazz BCA, Brizzi BRI, E-money Mandiri, and tap cash BNI. Research that combines diffusion innovation theory and technology acceptance models has also not been widely discussed in other research journals because this integration is still new. Researchers adding a variable named innovativeness. The desire for someone to look for something new and different is an innovation. Innovation is the main determinant for the adoption of technology even though innovation is not included in the dominant theoretical model of technology acceptance[41].

For future research, it is suggested to adding more variables such as brand image, trust, and attitude. This is important because a well-known and reputable bank brand can increase customer trust in using the bank's emoney card products and can influence their attitudes and intention in using an e-money card. For the banks, they must improve the innovation in making an emoney card. For example, a top-up for e-money Mandiri is often offline so it is inefficient because if a user only has e-money Mandiri then the user is forced to buy other e-money products. After all, users don't want their activities to be disrupted because they cannot top-up emoney Mandiri balances.

Banks can make innovations like users can top up emoney cards through OVO, DANA, etc because financial technology usually often does promotional offers so banks can collaborate with that financial technology about e-money top-up systems. On the other hand, especially for the toll road area, it can provide a separate e-money top up the place with toll payments so when paying tolls, no need to queue for long.

\section{AUTHORS' CONTRIBUTIONS}

The first author developed the theoretical formalism and the second author did the survey. Further, the analysis of the data gathered from the survey was conducted by the first author while the second author wrote the manuscript under the guidance of the first author. The final manuscript was then edited by the first author.

\section{REFERENCES}

[1] Muttaqin, "Sosialisasi Gerakan Nasional Non Tunai (GNNT) Pentingkah?," Kompasiana, 2018.

[2] Z. DA, "Inilah 5 Produk e-Money Terbaik dan Terpopuler di Indonesia (Updated) _ BukaReview," Bukalapak, no. October, p. 66198, 2019, [Online]. Available: https://review.bukalapak.com/finance/5layanan-e-money-dan-e-wallet-dari-bank-terbaik-danterpopuler-di-indonesia-66198.

G. Yudistira, "Transaksi uang elektronik naik 375\% sampai Agustus 2018,” Kontan.co.id, Sep. 2018.

Y. A. Rahayu, "Strategi Bank Mandiri Hadapi Persaingan Ketat Bisnis E-Money merdeka," merdeka.com, 2019.

[5] F. D. Davis, R. P. Bagozzi, and P. R. Warshaw, "User Acceptance of Computer Technology: A Comparison of Two Theoretical Models," Manage. Sci., vol. 35, no. $8, \quad$ pp. 982-1003, 1989, doi: 10.1287/mnsc.35.8.982.

[6] Y. J. Joo, K. Y. Lim, and E. K. Kim, "Online university students' satisfaction and persistence: Examining perceived level of presence, usefulness and ease of use as predictors in a structural model," Comput. Educ., vol. 57, no. 2, pp. 1654-1664, 2011, doi: 10.1016/j.compedu.2011.02.008.

[7] K. Rouibah, T. Ramayah, and O. S. May, "Modeling User Acceptance of Internet Banking in Malaysia : a Partial Least Square ( Pls ) Approach," IGI Glob. Publ., pp. 1-23, 2011.

[8] V. V. Coa and J. Setiawan, "Analyzing Factors Influencing Behavior Intention to Use Snapchat and Instagram Stories," Int. J. New Media Technol., vol. 4, no. 2, pp. 75-81, 2017, doi: 10.31937/ijnmt.v4i2.783.

[9] G. Chen, C. Luo, and H. Xu, "Understanding usage intention of social media's innovative functions: Based on expanded innovation diffusion theory," Proc. Int. Conf. Electron. Bus., vol. 2018-Decem, pp. 700-709, 2018.

[10] E. M. Rogers, Diffusion of innovations. New York, NY: Free Press, 2003.

[11] R. Bhagat and S. Sambargi, "Evaluation of personal innovativeness and perceived expertise on digital marketing adoption by women entrepreneurs of micro and small enterprises," Int. J. Res. Anal. Rev., vol. 6, no. 1, pp. 338-351, 2019.

[12] V. Ratten, "Continuance use intention of cloud computing: Innovativeness and creativity perspectives," J. Bus. Res., vol. 69, no. 5, pp. 17371740, 2016, doi: 10.1016/j.jbusres.2015.10.047.

[13] A. T. F. Lou and E. Y. Li, "Integrating innovation diffusion theory and the technology acceptance model: The adoption of blockchain technology from business managers' perspective," Proc. Int. Conf. Electron. Bus., vol. 2017-Decem, pp. 299-302, 2017.

[14] E. Roussou, I., \& Stiakakis, "Adoption of Digital Currencies by Companies in the European Union: A Research Model combining DOI and TAM," in 4 th International Conference on Contemporary Marketing Issues ICCMI June 22-24, 2016 Heraklion, Greece, 2016, p. 163.

[15] S. Min, K. K. F. So, and M. Jeong, "Consumer adoption of the Uber mobile application: Insights from diffusion of innovation theory and technology acceptance model," J. Travel Tour. Mark., vol. 36, no. $7, \quad$ pp. 770-783, 2019, doi: 10.1080/10548408.2018.1507866.

[16] W. M. Al-rahmi, N. Yahaya, M. M. Alamri, Y Alyoussef, A. M. Al-rahmi, and Y. Bin Kamin, "Integrating innovation diffusion theory with technology acceptance model : supporting students , attitude towards using a massive open online courses ( MOOCs ) systems," Interact. Learn. Environ., vol. 
0 , no. $0, \quad$ pp. $1-13, \quad 2019$, doi: 10.1080/10494820.2019.1629599.

[17] W. M. Al-Rahmi et al., "Integrating Technology Acceptance Model with Innovation Diffusion Theory: An Empirical Investigation on Students' Intention to Use E-Learning Systems," IEEE Access, vol. 7, pp. 26797-26809, 2019, 10.1109/ACCESS.2019.2899368.

[18] T. Teo, M. Zhou, A. C. W. Fan, and F. Huang, "Factors that influence university students' intention to use Moodle: a study in Macau," Educ. Technol. Res. Dev., vol. 67, no. 3, pp. 749-766, 2019, doi: 10.1007/s11423-019-09650-x.

[19] J. M. Vallejo and I. M. Polo, "Understanding online businesssimulation games: the role of flow experience, perceived enjoyment and personal innovativeness," Australas. J. Educ. Technol., 2019, doi: https://doi.org/10.14742/ajet.3862.

[20] M. S. Lee, "Effects of personal innovativeness on mobile device adoption by older adults in South Korea: the moderation effect of mobile device use experience," Int. J. Mob. Commun., vol. 17, no. 6, p. 682, 2019, doi: 10.1504/ijmc.2019.102719.

[21] R. Septiani, P. W. Handayani, and F. Azzahro, "Factors that Affecting Behavioral Intention in Online Transportation Service: Case study of GOJEK," Procedia Comput. Sci., vol. 124, pp. 504-512, 2017, doi: 10.1016/j.procs.2017.12.183.

[22] O. Isaac, A. M. Mutahar, N. M. Daud, T. Ramayah, and A. H. Aldholay, "The effect of awareness and perceived risk on the technology acceptance model (TAM): mobile banking in Yemen," Int. J. Serv. Stand., vol. 12, no. 2, p. 180, 2018, doi: 10.1504/ijss.2018.10012980.

[23] X. (2019) Yang, Y., \& Wang, "Modeling the intention to use machine translation for student translators: An extension of Technology Acceptance Model," Comput. Educ., vol. 133, pp. 116-126, 2019, doi: https://doi.org/10.1016/j.compedu.2019.01.015.

[24] F. Lin, S. S. Fofanah, and D. Liang, "Assessing citizen adoption of e-Government initiatives in Gambia: A validation of the technology acceptance model in information systems success," Gov. Inf. Q., vol. 28, no. 2, pp. 271-279, 2011, doi: 10.1016/j.giq.2010.09.004.

[25] F. D. Davis, "Perceived usefulness, perceived ease of use, and user acceptance of information technology," MIS Q. Manag. Inf. Syst., vol. 13, no. 3, pp. 319-339, 1989, doi: $10.2307 / 249008$.

[26] H. W. Kim, H. C. Chan, and S. Gupta, "Value-based adoption of mobile internet: an empirical investigation.," Decis. Support Syst., vol. 43, no. 1, pp. 111-126, 2007.

[27] J. W. Moon and Y. G. Kim, "Extending the TAM for a World-Wide-Web context," Inf. Manag., vol. 38, no. 4, pp. 217-230, 2001, doi: 10.1016/S03787206(00)00061-6.

[28] R. Agarwal and J. Prasad, "A Conceptual and Operational Definition of Personal Innovativeness in the Domain of Information Technology," Inf. Syst. Res., vol. 9, no. 2, pp. 204-215, 1998, doi: 10.1287/isre.9.2.204.

[29] M. Tan and T. S. H. Teo, "Factors Influencing the
Adoption of Internet Banking," J. Assoc. Inf. Syst., vol. 1, no. 5, pp. 1-44, 2000, doi: 10.1016/j.elerap.2008.11.006.

[30] S. Taylor and P. Todd, "Decomposition and crossover effects in the theory of planned behavior: A study of consumer adoption intentions," Int. J. Res. Mark., vol. 12, no. 2, pp. 137-155, 1995, doi: 10.1016/01678116(94)00019-K.

[31] C. R. Kothari, Research methodology: Methods and techniques., 2nd ed. New Delhi: New Age International, 2004.

[32] R. Hamdollah and P. Baghaei, Partial least squares structural equation modeling with $R$, vol. 21 , no. 1 . 2016.

[33] J. F. Hair, W. Black, B. Babin, and R. Anderson, Multivariate Data Analysis, 8th ed. Boston, MA: Cengage Learning EMEA, 2018.

[34] H. Taherdoost, "A review of technology acceptance and adoption models and theories," Procedia Manuf., vol. 22, pp. 960-967, 2018, doi: 10.1016/j.promfg.2018.03.137.

[35] A. K. Ainur, M. D. Sayang, Z. Jannoo, and B. W. Yap, "Sample size and non-normality effects on goodness of fit measures in structural equation models," Pertanika J. Sci. Technol., vol. 25, no. 2, pp. 575-586, 2017.

[36] B. Beers, "P-Value Definition beers," Investopedia, 2020. .

[37] J. Henseler, "Bridging Design and Behavioral Research With Variance-Based Structural Equation Modeling," J. Advert., vol. 46, no. 1, pp. 178-192, 2017, doi: 10.1080/00913367.2017.1281780.

[38] J. K. C. Zailani, S., Iranmanesh, M., Nikbin, D., \& Beng, "Determinants of RFID adoption in Malaysia's healthcare industry: occupational level as a moderator.," J. Med. Syst., vol. 39, no. 1, p. 172, 2015, doi: https://doi.org/10.1007/s10916-014-01724.

[39] M. S. Lee, "Effects of personal innovativeness on mobile device adoption by older adults in South Korea: the moderation effect of mobile device use experience.," J. Mob. Commun., vol. 17, no. 6, pp. 682-702, 2019, doi: https://doi.org/10.1504/IJMC.2019.102719.

[40] F. Septiani, R., Handayani, P. W., \& Azzahro, "Factors that affecting behavioral intention in online transportation service: Case study of GO-JEK," in Procedia Computer Science, 124, 2017, pp. 504-512, doi: https://doi.org/10.1016/j.procs.2017.12.183.

[41] E. L. Slade, Y. K. Dwivedi, N. C. Piercy, and M. D. Williams, "Modeling Consumers' Adoption Intentions of Remote Mobile Payments in the United Kingdom: Extending UTAUT with Innovativeness, Risk, and Trust," Psychol. Mark., vol. 32, pp. 860873, 2015, doi: 10.1002/mar.20823. 